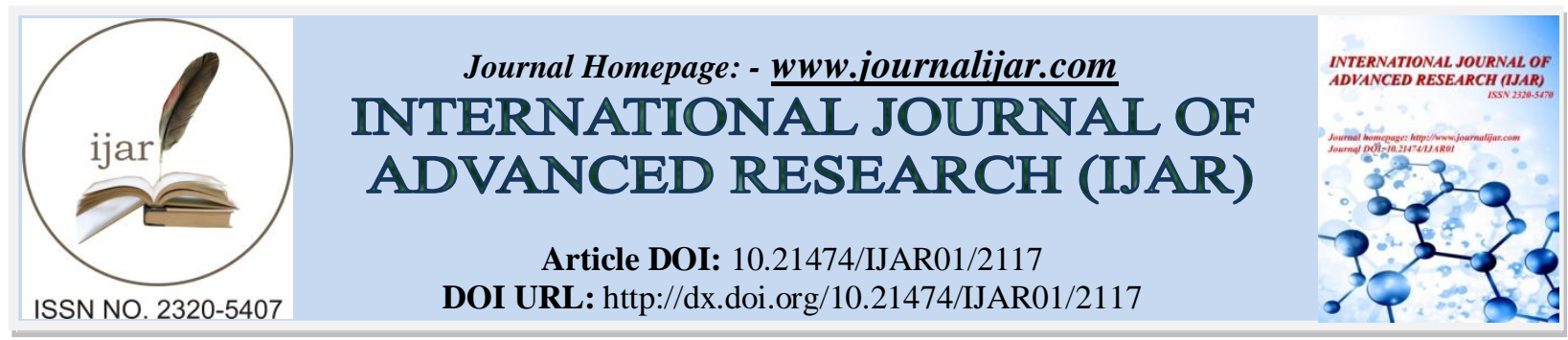

RESEARCH ARTICLE

\title{
THE ROLE OF EDUCATION TOWARDS WOMEN EMPOWERMENT IN INDIA.
}

\author{
Dr. Rita Khatri.
}

H.R College of Commerce and Economics, Churchgate, Mumbai.

\section{Manuscript Info}

Manuscript History

Received: 25 September 2016

Final Accepted: 27 October 2016

Published: November 2016

Key words:-

Women Empowerment, literacy and education, Economic development.

\begin{abstract}
Today women play the leading role in developing the society. Society cannot be created without the active contribution of women. In India women do not use their rights and neither are considered independent to take any decision. In order to provide equal status in the society women need to be empowered.Women's empowerment in India is heavily dependent on many different variables that includes geographical location (urban/rural), educational status, social status (caste and class), and age. Policies on women's empowerment exist at the national, state, and local (Panchayat) levels in many sectors, including health, education, economic opportunities, gender-based violence, and political participation. However, there are significant gaps between policy formation and actual implementation at the community level. Women can be empowered only when they are literate and educated .Education is the key to unlock the golden door of freedom for development. Of Indian women today, the female literacy levels according to the Literacy Rate 2011 census has been $65.46 \%$ where the male literacy rate has been over $80 \%$. Being literate or having only primary education is not enough to enhance productivity or to obtain better-paying jobs but it is essential for women to pursue the higher education.Even beyond literacy there is much that education can do for women's rights, dignity and security. Therefore this research paper discusses the impact of literacy and education on empowerment of women as well as the suggestion to improve the changes that need to be considered for women empowerment and economic development.
\end{abstract}

Copy Right, IJAR, 2016,. All rights reserved.

\section{Introduction:-}

"Woman is an incarnation of 'Shakti' - the Goddess of Power. If she is bestowed with education, India's strength will double. Let the campaign of 'Kanya Kelavni' be spread in every home; let the lamp of educating daughters be lit up in every heart “

Prime Minister Narendra Modi

Education is the most important requirement and the fundamental right for any citizen. It help the individual to reduce inequality and play a central role in human development that impacts the overall social economic development. Higher level of literacy and education leads to better attainment of health, nutritional status, economic growth, population control, empowerment of the weaker sections and community as a whole. In context to this over the decades societies have been trying to develop without giving any rights to women. There has always been a gender discrimination toward the development of women. Men are empowered in the society and women are 
considered as their servant. Women do not have their rights and neither are considered independent to take any decision.In order to provide equal status in the society women need to be empowered. Empowerment is a process of acquiring knowledge and awareness which enable them to move towards life with greater dignity and self assurance.Women empowerment includes women awareness of their rights, self-confidence, to have a control over personal and professional lives and their ability to bring a change in the society. Empowerment has many elements i.e. economic, social, political and personal. Economic empowerment means to give woman her rights in the economy. Social empowerment means status of woman in the society should be equal to man by eliminating injustice and inequity. Political empowerment means women should have seats in provincial and national assemblies and giving one woman right of one vote. Personal empowerment means women should have freedom in their personal matters. Women contribute to their families, societies and countries financially. This brings development in the economy.

Women empowerment as a concept was introduced at the International women Conference in 1985 at Nairobi, which defined it as redistribution of social power and control of resources in favour of women.Empowerment of women is empowerment of family/household and in turn development of a nation. Empowerment of women leads to benefit not only to the individual woman or to women groups, but also to the families and community as a whole through collective action for development.The United Nation's Organization had declared the year 1975 as women's year and the decade 1975-1985 as women's decade on an international level. Women can never achieve empowered till they attained the literacy and education. Women education in India plays a very important role in the overall development of the country. It not only helps in the development of half of the human resources, but in improving the quality of life at home and outside.

\section{Objectives of the study:-}

- To understand the concept of women empowerment.

- To study the role of education towards empowerment of women.

\section{Methodology of the study:-}

The present study is based on the collection of data from secondary sources. Secondary data is obtained from various published and unpublished records, books, magazines and journals.

\section{Review Of Literature:-}

1. Amartya Sen(1999) makes a compelling case for the notion that societies need to see women less as passive recipients of help, and more as dynamic promoters of social transformation, suggesting that the education, employment and ownership rights of women have a powerful influence on their ability to control their environment and contribute to economic development.

2. According to President Bill Clinton at Clinton global initiative(2009) Women perform 66 percent of the world's work, and produce 50 percent of the food, yet earn only 10 percent of the income and own 1 percent of the property. Whether the issue is improving education in the developing world, or fighting global climate change, or addressing nearly any other challenge we face, empowering women is a critical part of the equation.

3. According to Duflo(2011) Women empowerment and economic development are closely related in one direction, development alone can play a major role in driving down inequality between men and women in the other direction, empowering women may benefit development. The study argues that the inter-relationships of the empowerment and development are probably too weak to be self sustaining and that continuous policy commitment to equality for its own sake may be needed to bring about equality between men and women as even today small numbers of women work and for the same work they earn less than men.

4. Doepke, M., Tertilt, M. (2011). This study is an empirical analysis suggesting that money in the hands of mothers (as opposed to their husbands) benefits children. This study developed a series of noncooperative family bargaining models to understand what kind of frictions can give rise to the observed empirical relationships.

\section{Status of Education and Women Empowerment in India:- Women empowerment:-}

Over the last few years India has emerged as one of leading nations for international business and it has been estimated that by 2020 it will be more literate, knowledgeable and economically at the forefront. No doubt, women will play a vital role in contributing to the country's development. Women power is crucial to the economic growth 
of any country. In India this is yet to meet the requirements as very little has been achieved in the area of women empowerment, but for this to happen, this sector must experience a chain of reforms. Though India could well become one of the largest economies in the world, it is being hindered due to a lack of women's participation. Women have the potential to change their own economic status, as well as that of the communities and countries in which they live. Yet more often than not, women's economic contributions go unrecognized, their work has been undervalued and their promise unnourished.

Gender Gap Index 2012 (GGI) measures the gap between men and women in four fundamental categories economic participation \& opportunity, educational attainment, health \& survival and political empowerment. India ranks among the lowest 105 in 135 Countries, below countries like China, Sri Lanka and Bangladesh as shown in Table 1.

Table 1:- Details of Gender gap Index 2012(out of 135 countries).

\begin{tabular}{|l|l|l|l|l|}
\hline & \multicolumn{2}{|c|}{ India } & \multicolumn{2}{c|}{ Srilanka } \\
\hline Gender Gap sub indices & Rank & Scores & Rank & Scores \\
\hline 1.Economic Participation and opportunity & 123 & 0.4588 & 105 & 0.5596 \\
\hline 2 Education Attainment & 121 & 0.8525 & 48 & 0.9946 \\
\hline 3. Health and survival & 134 & 0.9312 & 1 & 0.9676 \\
\hline 4.Political Empowerment & 17 & 0.3343 & 22 & 0.3151 \\
\hline Over all Index & 105 & 0.6442 & 39 & 0.7122 \\
\hline
\end{tabular}

Source: World Economic Forum (2012) Global Gender gap Index 2012.

Table: 1 clearly depicts the status of low level of attainment of women in the varied field of their attainment. Keeping aside the Political Empowerment, the other three indices is all above the rank of 100. The Political Empowerment ranks quite high may be due to the 73rd and 74th Constitution Amendments of India providing greater opportunity to women to take part in active politics. This mirrors the status of women in India and gender discrimination in all aspects of life-education, economic activity and empowerment.

\section{Literacy and Education:-}

Literacy and Education are important indicators in a society and play a central role in human development that impacts overall social-economic development. Higher levels of literacy and education lead to better attainment of health and nutritional status, economic growth, population control, empowerment of the weaker sections and community as a whole. Also,higher literacy rates improve development indicators consistently. As per the provisional figures of Census 2011, in India 77,84,54,120 persons have been counted as literates. Among all literates, 33,42,50,358 are females, whereas 44,42,03,762 are males. The literacy rate of India in 2011 is 74.0 per cent. Literacy rate among females is 65.5 per cent whereas the literacy rate among males is 82.1 per cent. Literacy rate for females is showing an increasing trends since 1981. Table 2 highlights the literary rate for females as per census 2011

Table 2:- Literacy rate: India 1981 to 2011

\begin{tabular}{|l|l|l|l|l|}
\hline Year & \multicolumn{2}{|l|}{ Literate rate } & Gap in literacy \\
\hline & Person & Male & Female & \\
\hline $\mathbf{1 9 8 1}$ & 43.6 & 56.4 & 29.8 & 26.6 \\
\hline $\mathbf{1 9 9 1}$ & 52.2 & 64.1 & 39.3 & 24.8 \\
\hline $\mathbf{2 0 0 1}$ & 64.8 & 75.3 & 53.7 & 21.6 \\
\hline $\mathbf{2 0 1 1}$ & 74.1 & 82.1 & 65.5 & 16.6 \\
\hline
\end{tabular}

Source: Census of India 2011

Note: Literacy rate for 1981, 1991, 2001 and 2011 Census relates to the population aged seven years and above

As per Table 3 the adult literacy rate (15+) for male has increased from 73.4 in 2001 to 78.8 in 2011 whereas increase in adult literacy is more in case of females from 47.8 to 59.3 from 2001 to 2011. In 2011, more than half of the rural adult females are literate against $76.9 \%$ urban females. $88.3 \%$ of urban adult males are literate against 74.1 rural adult males. Overall adult literacy is increasing in India. 
Table 3:- Adult literacy rate 2011

\begin{tabular}{|l|l|l|l|l|}
\hline Residence & Male & Female & Total & $\begin{array}{l}\text { Gender parity } \\
\text { Index }\end{array}$ \\
\hline Rural & 74.1 & 50.6 & 62.6 & $68 \%$ \\
\hline Urban & 88.3 & 76.9 & 82.8 & $87 \%$ \\
\hline Total & 78.8 & 59.3 & 69.3 & $75 \%$ \\
\hline Residence Parity Index & $84 \%$ & $66 \%$ & $76 \%$ & \\
\hline
\end{tabular}

Source: Census of India, Office of the Registrar General, India.

Moreover, for women to be competitive in today's world, they need secondary schooling and training in skills that are appropriate for the market place. Being literate or having only primary education is not enough to enhance productivity or to obtain better-paying jobs.A recent study found that in India the wage benefits for women with secondary education was double than that for men. This result is consistent with studies in other countries. Table 4 highlights the number of girls enrolled in primary, middle and secondary education in India.

Table 4:- Number of girls per 100 boys enrolled in school in India

\begin{tabular}{|l|l|l|l|}
\hline Year & Primary ( I -IV) & Upper Primary(V-VIII) & Secondary(IX-X) \\
\hline $2000-01$ & 78 & 69 & 63 \\
\hline $2006-07$ & 88 & 82 & 73 \\
\hline $2007-08$ & 91 & 84 & 77 \\
\hline $2009-10$ & 92 & 88 & 82 \\
\hline $2010-11$ & 92 & 89 & 82 \\
\hline $2012-13(\mathrm{p})$ & 94 & 95 & 89 \\
\hline $2013-14(\mathrm{p})$ & 93 & 95 & 90 \\
\hline
\end{tabular}

Source: Flash Statistics 2013-14 and DISE Stastistics 2013-14,

* P- Provisional

Higher levels of education have greater economic returns for women than men.Women with higher levels of education also are more likely to work in the formal employment market (where earnings are higher) versus being self-employed or engaging in informal work. As shown in Table 5 there has been considerable progress for females enrolling for higher education.After independence, to promote higher education of women government established separate women universities and women colleges. During the last six decades, no. of women colleges increased by nearly 10 times but the percentage of women colleges to total colleges remains more or less same i.e. about $12 \%$. This shows awareness about women higher education in the society.

Table 5:- Number of Females per 100 Males in University Education in Major Disciplines

\begin{tabular}{|l|l|l|l|l|l|}
\hline Year & Arts & Science & Commerce & Engineering & Medicine \\
\hline $2000-01$ & 81.4 & 61.4 & 55.3 & 28.7 & 68.2 \\
\hline $2001-02$ & 7.8 & 64.2 & 63.1 & 33.1 & 68.4 \\
\hline $2002-03$ & 82.24 & 60.55 & 57.95 & 29.17 & 71.19 \\
\hline $2003-04$ & 85.70 & 75.90 & 51.20 & 17.5 & 72.5 \\
\hline $2004-05$ & 87.3 & 84.3 & 51.6 & 31.1 & 53.1 \\
\hline $2005-06$ & 77.7 & 71.2 & 65.2 & 36.1 & 90.1 \\
\hline $2006-07$ & 76.9 & 71.2 & 60.9 & 35.8 & 89.5 \\
\hline $2007-08$ & 79.6 & 71.0 & 63.53 & 39.3 & 88.31 \\
\hline $2008-09$ & 86.80 & 66.90 & 65.30 & 39.7 & 88.31 \\
\hline $2009-10$ & 86.0 & 72.7 & 67.3 & 40.3 & 90.9 \\
\hline
\end{tabular}

Source: Department of Secondary \& Higher Education, Ministry of Human Resource Development at http://www.mospi.gov.in/sites/default/files/reports_and_publication/statistical_publication/social_statistics/Chapter_ 3.pdf

\section{Suggestions for upliftment of Indian women:-}

- Women empowerment is an essential element for national development. Since women constitutes half of the population there can be no development unless the needs and interests of women are fully taken into account. Therefore whenever policies are amended or new policy are initiated government has to consider the interest of women towards the new policy initiative. For examples as government has initiated 'Make in India' project they 
should provide concessional interest for bank loan and single window clearance for women entrepreneurs who are participating in this campaign. This initiative will encourage more women to be entrepreneur.

- More and more awareness for women empowerment through education need to be undertaken through free workshop and seminars, women councils in rural areas as even today many women are not aware of their basic rights.In order to motivate rural women for higher education some scholarships should be announced for rural women and government should ensure that this educational scholarship should go to deserving candidates.

- The government body or NGO should arrange programmes for interaction with other empowered women in the society for motivating women. The institutions that are engaged in various fields of social work can start short term diploma or certificate courses in areas of rural development with special emphasis on projects for women's development. Even many female celebrities can participate in these progammes toward empowering women as they are the effective role model for many to follow.

- Health care and education are the least considered sector in financial budget as compared to the rest of the world. It is imperative on the part of the government to scale up the investment in education and health sector for women. The government should increase investment to achieve gender parity and higher level of enrollment in completion of secondary and tertiary education. Provide women and girls better health care services, social services, decent employment and other support so that they are able to achieve full benefit of education.

- As a corporate social responsibility even the corporate players should also take active interest towards the project related to empowering women by investing funds towards women literacy and education, health and safety of girl child, skill development centres for women entrepreneurs, higher education. Their contribution can change the lives of many women in India.

\section{Conclusion:-}

Without women contribution towards society cannot be ignored. When thewomen is empowered it mean the whole family is empowered and the overall society is empowered. Education play key role towards empowerment. Women should pursue her education and career opportunities. They should fight for themselves for having better living standard and they should make their own decisions. For the development of the economy women and men both should work together and women should utilize their skills. Women empowerment is an essential element in national development. Since women constitute half of the population there can be no development unless the needs and interests of women are fully taken into account.The effective management and development of women's resources, their capabilities, interests, skills and potentialities are of paramount importance for the mobilization of human resources. Economic development efforts to combat poverty can only succeed if women are part of the solution.

\section{References:-}

1. Ganeswamurthy,(2008) "Empowerment of Women in India-Social Economics and Political", New Century Publications, New Delhi, p. 4.

2. Kochurani Joseph(2005) "Women Empowerment A conceptual Analysis", Vimala Books and Publications, Kanjirapally, 2005.

3. Rameshwari Pandya,(2008) "Women in changing India" Serials publications, Delhi

4. Sen, A. (1999). "Women's Agency and Social Change" Development as Freedom. Oxford University Press. New York.

5. Report (2005) "A second look on the role education plays in women empowerment" International Center for Research on Women (ICRW)

6. World report(2014) The role of women in development: Gender equality and sustainable development, United Nation Publication ISBN 978-92-1-130330-8

\section{Research Paper:-}

1. Baro and sarania (April 2014)"Employment and education status: Challenges of women empowerment in India"Pratidhwani the Echo-A Peer-Reviewed Indexed International Journal of Humanities \& Social Science Website: https://www.thecho.in ISSN: 2278-5264 (Online) ISSN: 2321-9319 (Print)

2. Duflo. (2011). Women's Empowerment and Economic Development. NBER Working paper No. 17702.

3. Dr Kadam Namdkumar, (2014) "Women In Higher Education: Position And Prospects", Wamayug Research Journal ISSN - $2348-7224$ Www.Wamayug.Com

4. Deopke and tertilt (2011) "Does women empowerment promotes economic development"available at http://thred.devecon.org/papers/2011/2011-038_Doepke_Does-Female-Empowerment.pdf 
5. Hazarika,(2011) "Women Empowerment in India: A Brief Discussion" International Journal of Educational Planning \& Administration. ISSN 2249-3093 Volume 1, Number 3 (2011), pp. 199-202.

6. Hussain and Jadhav (2013) "Role of Higher Education in women empowerment: A study" International journal for administration in management, commerce and economics issue : 1 (05-12-2013) ISSN : 2347 - 9558

7. Mamta Mokta (2014) "Empowerment of women in India: A critical analysis" Indian journal of public administration vol. lx, no. 3, July-September 2014.

8. R.R. Kumari and K.N. Yadav,(2008)"Economic Reform and Empowerment of Women: Issues, Options and Concerns", in N.K. Thakur and R.N. Thakur (eds) Impact of Economic Reform Policies on Dalit and Weaker Sections, Deep \& Deep Publications, New Delhi, p. 106.

9. Reecha upadhay "Women Empowerment in India :An analytical review", Asia foundation

10. Suman Panucha and Ankita Khatik,(2005) "Empowerment of Rural Woman", Social Action, Vol. 55, p. 349.

11. Suguna (2011) "Education And Women Empowerment In India" Zenith International Journal Of Multidisciplinary Research Vol.1 Issue 8, December 2011, ISSN 22315780.

12. Sharma and Afroz(2014) "Women Empowerment Through Higher Education" International Journal of Interdisciplinary and Multidisciplinary Studies (IJIMS), Vol 1, No.5, 18-22

13. Sohail (2014), “'Women empowerment and economic development-an exploratory study in pakistan”, journal of business studies quarterly 2014, volume 5, number 4 ISSN 2152-1034 .

\section{Other references:-}

1. Clinton(2009) clinton global initiative available at http://press.clintonglobalinitiative.org/press_

2. http://www.undp.org/content/dam/undp/library/corporate/fast-facts/english/FF-Gender-Equality-andUNDP.pdf

3. http://www.care.org/work/womens-empowerment/women

4. http://www.goldmansachs.com/our-thinking/archive/archive-pdfs/brics-book/brics-chap-10.pdf

5. http://www.thechicagocouncil.org/UserFiles/File/GlobalAgDevelopment/Report/GirlsGrowReportFinal_v9.pd $\mathrm{f}$

6. www.actionaid.org.uk/sites/default/files/publications/womens_rights_on-line_version_2.1.pdfWorld

Bank, World Development Report 2012. p. 80.

7. http://mhrd.gov.in/higher_education

8. http://mhrd.gov.in/sites/upload_files/mhrd/files/statistics/EAG2014.pdf 